\title{
KARAKTERISTIK SIFAT FISIKA KIMIA KARAGINAN RUMPUT LAUT Kappaphycus alvarezii PADA BERBAGAI UMUR PANEN YANG DIAMBIL DARI DAERAH PERAIRAN DESA ARAKAN KABUPATEN MINAHASA SELATAN
}

\author{
Selvanda M Bunga, Roike I Montolalu, Johanna W Harikedua, Lita ADY Montolalu, \\ Alexander H Watung dan Nurmeilita Taher.
}

Fakultas Perikanan dan Ilmu Kelautan, Universitas Sam Ratulangi, Manado, Sulawesi Utara.

\begin{abstract}
ABSTRAK
Rumput laut Kappaphycus alvarezii merupakan salah satu komoditas unggulan penghasil karaginan yang banyak dimanfaatkan dalam industri kertas, tekstil, fotografi, pasta dan pengalengan ikan. Karaginan dipakai dalam bebaragi industri karena berfungsi sebagai pengatur keseimbangan, bahan pengental, pembentuk gel, dan pengemulsi. Penelitian ini dilakukan dengan tujuan untuk mengetahui dan membandingkan sifat fisika kimia karaginan rumput laut dari berbagai umur panen, serta menentukan umur panen yang tepat. Penelitian dilakukan 2 tahap, tahap pertama penanaman rumput laut di daerah perairan desa Arakan dan diambil dalam waktu 0 (bibit), 10, 20, 30, 40 dan 50 hari. Dari hasil penelitian didapatkan bahwa rendemen karaginan tertinggi diperoleh dari perlakuan 20 hari $(28,402 \%)$, kadar air terendah diperoleh pada hari ke $30(13,76 \%)$, kadar abu terendah diperoleh pada hari ke $30(16,19 \%)$, nilai viskositas terendah diperoleh pada hari ke 20 dan 50 (60 cps) dan kekuatan gel tertinggi diperoleh pada hari ke $50\left(78,505 \mathrm{~g} / \mathrm{cm}^{2}\right)$. Karakteristik kimia untuk parameter kadar air, tidak memenuhi standard yang ditetapkan (12\%) dan karakteristik fisika untuk parameter kekuatan gel juga belum memenuhi standard yang ditetapkan $\left(900-1200 \mathrm{~g} / \mathrm{cm}^{2}\right)$. Hasil Penelitian ini, diharapkan bisa memberi informasi tentang kandungan fisika kimia karaginan yang terkandung dalam rumput laut dalam perannya di bidang industri perikanan dan kelautan.
\end{abstract}

Kata kunci: karaginan, umur panen, Kappaphycus alvarezii.

\section{PENDAHULUAN}

Rumput laut merupakan salah satu komoditi yang berperan sebagai penyumbang utama produksi sektor perikanan budidaya. Setiap tahun produksi rumput laut terus mengalami peningkatan, dari 2,574 juta ton pada tahun 2009 menjadi 3,082 juta ton pada tahun 2010, dan Indonesia merupakan salah satu negara produsen rumput laut berkaraginan terbesar dunia, sekitar $90 \%$ pasar dunia telah dikuasai oleh Indonesia (Anonimous, 2011a). Kementerian Perdagangan mencatat nilai ekspor rumput laut pada 2010 mencapai US\$135,939 juta. Pada Januari-Juni 2011, nilai ekspor mencapai US $\$ 83,283$ juta atau naik $41 \%$ dari periode serupa di 2010 (Anonimous 2011b).

Rumput laut Kappaphycus alvarezii merupakan salah satu komoditas unggulan penghasil karaginan yang banyak dimanfaatkan dalam industri kertas, tekstil, fotografi, pasta dan pengalengan ikan. Pada tahun 2002, produksi karaginan Indonesia mencapai 3.896 ton dan yang diekspor sebanyak 3.156 ton $(80$ persen). Selama 1996-2004, produksi dan ekspor karaginan Indonesia relatif konstan, dengan pertumbuhan masing-masing $2,92 \%$ dan $2,49 \%$ per tahun (S. Emma $d k k$., 2010).

Dari data Institut Medical Research internasional, kebutuhan karaginan dunia saat ini sekitar 50 ribu ton dan meningkat rata-rata $3 \% /$ tahun. Jika pertumbuhan kebutuhan karaginan tersebut bisa meningkat pesat sampai $25 \% /$ tahun, kebutuhan karaginan dunia pada 2014 baru menyentuh angka 100 ribu ton (Anonimous, 2010).

Provinsi Sulawesi Utara menyimpan potensi pengembangan budidaya rumput laut, salah satunya jenis $E$. cottonii atau $K$. alvarezii. Rumput laut penghasil kappa karaginan ini telah dibudidayakan pada beberapa lokasi, salah satunya di daerah perairan Desa Arakan kecamatan Tatapaan, Minahasa Selatan. Potensi budidaya di perarian Arakan $\pm 1.500 \mathrm{Ha}$, dan telah termanfaatkan untuk budidaya rumput laut $450 \mathrm{Ha}$. Produksi rumput laut dari perairan desa Arakan pada tahun 1992-2000 mencapai 1502000 ton kering per bulan, namun pada tahun 2006-2012 produksi rumput laut mengalami penurunan yaitu 1-5 ton kering per bulan. 
Melihat kegunaan karaginan dalam berbagai bidang dan dan makin meningkatnya permintaan luar negeri, maka produksi karaginan perlu ditingkatkan dengan meningkatkan produksi $E$. cottonii atau $K$. alvarezii. Dengan demikian, perlu adanya studi tentang karakteristik fisika kimia karaginan dari rumput laut $K$. alvarezii pada berbagai umur panen yang diambil di daerah perairan desa Arakan, Kabupaten Minahasa Selatan Provinsi Sulawesi Utara.

Untuk membuktikan beberapa penelitian yang pernah dilakukan sebelumnya, bahwa umur panen (30-55 hari) sangat berpengaruh pada karakteristik fisika kimia karaginan rumput laut, maka penelitian ini dimulai dari perlakuan 0 hari (bibit) sampai 50 hari. Tujuan penelitian ini adalah a). untuk mengetahui karakteristik sifat fisika kimia karaginan rumput laut $K$. alvarezii dari berbagai umur panen yang diambil dari daerah perairan desa Arakan; b). membandingkan kandungan karaginan rumput laut dari berbagai umur panen yang diambil dan ; c). menentukan umur panen yang tepat sesuai dengan karakterisktik sifat fisika kimia karaginan yang terkandung dalam rumput laut.

\section{METODOLOGI PENELITIAN}

\section{Alat dan Bahan}

Alat yang digunakan terdiri atas satu unit alat ekstraksi karaginan, yaitu penangas, Hot plate, Filtering flash, kain kasa, gunting, timbangan eletrik, wadah plastik dan peralatan untuk pengujian karakteristik karaginan, yaitu Texture analyzer XT plus, Viscosmeter Brookfield RVT, oven, tanur, cawan porselin, tang penjepit, desikator, timbangan analitik, thermometer batang, $\mathrm{pH}$ meter, petridish, serta peralatan gelas. Bahan untuk penelitian ini terdiri atas: rumput laut, air tawar, Ethanol absolute, akuades, $\mathrm{NaOH}$ dan kertas lakmus.

\section{Tata Laksana Penelitian}

Sampel rumput laut dipanen dalam enam tingkat umur panen, yaitu $0,10,20,30$, 40 dan 50 hari. Masing-masing sampel diperlakukan sama mulai dari panen, perendaman dan pencucian. Rumput laut dicuci dengan air bersih dan dikeringkan. Selanjutnya rumput laut dipotong-potong untuk memudahkan proses ekstraksi. Adapun tahap ekstraksi karaginan berdasarkan SNI.03-701990 sebagai berikut:
1. 5 g rumput laut yang telah dicuci dan dipotong-potong kecil dimasukkan ke dalam gelas piala.

2. Ditambahkan akuades sampai semua rumput laut terendam $+100 \mathrm{ml}$ selama 24 jam.

3. Setelah itu dicuci hingga bersih pada air yang mengalir.

4. Rumput laut dimasukan kembali kedalam gelas piala yang berisi akuades dan ditambahkan larutan $\mathrm{NaOH} 1 \%$.

5. $\mathrm{pH}$ sampel diatur sekitar 8,5-9 dengan menggunakan $\mathrm{pH}$ meter.

6. Sampel dipanaskan di atas penangas air pada suhu $70-90^{\circ} \mathrm{C}$ selama 3 jam, pada saat itu rumput laut hancur dan menjadi gel.

7. Disaring dalam keadaan panas dengan kain kasa menggunakan Filtering Flash dan pompa vakum yang di dalamnya berisi \pm 25 ml Ethanol absolut.

8. Hasil saringan ditampung dalam wadah plastik.

9. Dipindahkan ke dalam petridish yang telah diketahui beratnya kemudian dipanaskan dalam oven pada suhu $60^{\circ} \mathrm{C}$ selama 24 jam.

10. Setelah dingin, petridish ditimbang untuk mengetahui bobot rendemen karaginan.

\section{HASIL DAN PEMBAHASAN}

\section{Karakteristik Fisika Kimia Karaginan Rendeman Karaginan}

Analisis rendemen dilakukan untuk mengetahui persentase karaginan yang dihasilkan dari rumput laut kering yang digunakan berdasarkan umur panen.

Tabel 1. Data analisis rendemen karaginan (\%)

\begin{tabular}{ccccccc}
\hline \multicolumn{7}{c}{ Perlakuan (Hari) } \\
\hline Ulangan & $\mathbf{0}$ & $\mathbf{1 0}$ & $\mathbf{2 0}$ & $\mathbf{3 0}$ & $\mathbf{4 0}$ & $\mathbf{5 0}$ \\
\hline 1 & 19,33 & 18,36 & 25,40 & 26,99 & 29,32 & 25,30 \\
2 & 19,43 & 22,19 & 31,40 & 27,35 & 23,20 & 22,71 \\
\hline Total & 38,75 & 40,54 & 56,80 & 54,33 & 52,52 & 48,01 \\
\hline Rata-rata & 19,38 & 20,27 & 28,40 & 27,17 & 26,26 & 24,00 \\
\hline
\end{tabular}

Dari data yang diperoleh pada penelitian ini, rata-rata rendemen karaginan yang dihasilkan dari rumput laut pada umur panen yang berbeda berkisar 19,377-28,402\%. Jika dibandingn dengan standar minimum rendemen karaginan yang ditetapkan oleh depertemen perdagangan (1989) dalam Wenno (2009) (sebesar 25\%), maka ditemukan ada beberapa perlakuan yang memenuhi standar tersebut yakni pada perlakuan 20,30, 40 hari, sedangkan pada perlakuan 0,10 dan 50 hari masih belum memenuhi standar. 


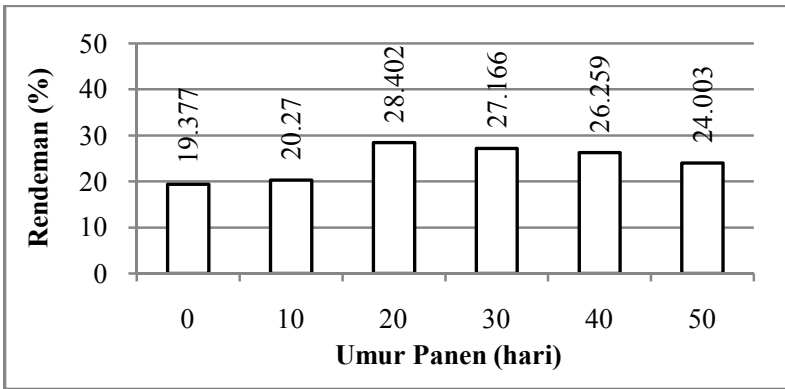

Gambar 1. Grafik rendemen karaginan pada umur yang berbeda

Pada penelitian ini, rendemen karaginan mengalami peningkatan pada $0-20$ hari kemudian mengalami penurunan pada perlakuan 30-50 hari. Hal ini diduga karena adanya penyakit ice-ice yang menyerang rumput laut pada perlakuan 30 hari, sehingga kandungan karaginan cenderung menurun seiring bertambahnya umur.

\section{Kadar Air}

Kadar air dihitung sebagai persen berat, artinya berapa gram air dalam setiap 100 gram berat karaginan (Harikedua, 2003). Kadar air karaginan sangat berpengaruh terhadap lamanya penyimpanan, karena berkaitan dengan aktivisat mikroba selama karaginan disimpan.

Tabel 2. Data analisis kandungan kadar air (\%).

\begin{tabular}{ccccccc}
\hline \multicolumn{7}{c}{ Perlakuan (Hari) } \\
\hline Ulangan & $\mathbf{0}$ & $\mathbf{1 0}$ & $\mathbf{2 0}$ & $\mathbf{3 0}$ & $\mathbf{4 0}$ & $\mathbf{5 0}$ \\
\hline 1 & 19,97 & 15,93 & 16,79 & 14,73 & 15,41 & 15,83 \\
2 & 18,96 & 17,80 & 13,97 & 12,80 & 15,25 & 14,41 \\
\hline Total & 38,93 & 33,73 & 30,76 & 27,53 & 30,66 & 30,24 \\
\hline Rata- rata & 19,46 & 16,86 & 15,38 & 13,76 & 15,33 & 15,12 \\
\hline
\end{tabular}

Data hasil pengujian kadar air karaginan pada penelitian ini rata-rata berkisar dari 13,76$19,46 \%$. Dari data di atas terlihat bahwa kadar air karaginan tertinggi terdapat pada perlakuan 0 hari yaitu sebesar $19,46 \%$, kemudian mulai menurun pada perlakuan 10 hari sampai terendah pada perlakuan 30 hari yaitu sebesar $13,76 \%$. Pada perlakuan 40 dan 50 hari, kandungan kadar air sedikit lebih tinggi dari perlakuan 30 hari, namun masih lebih rendah dari perlakuan 0-20 hari.

Hasil penelitian ini hampir sesuai dengan pernyataan Sukri (2006) dalam penelitiannya bahwa semakin tua umur panen, semakin rendah kandungan kadar air. Hal ini disebabkan karena semakin tua umur rumput laut, kandungan air bebasnya lebih banyak, sehingga penguapan saat penjemuran lebih besar terjadi maka akibatnya kandungan kadar airpun jadi lebih sedikit (Syamsuar, 2006).

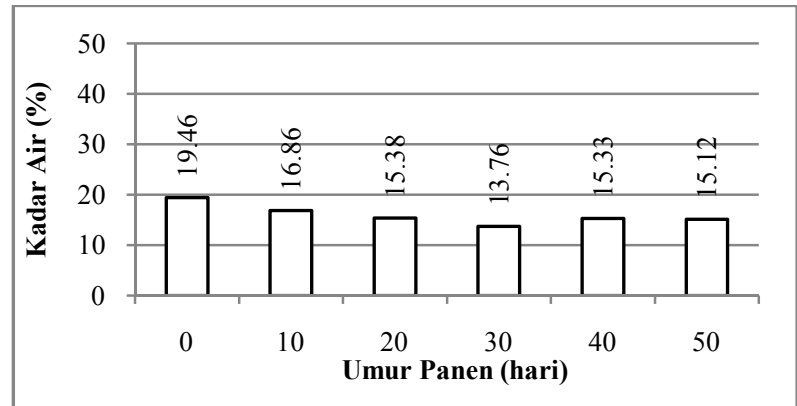

Gambar 2. Grafik air karaginan pada umur panen yang berbeda

\section{Kadar Abu}

Kadar abu yang dihasilkan karaginan pada penelitian ini rata-rata berkisar 16,19$22,44 \%$, dan masih memenuhi standar yang ditetapkan oleh FAO dan EEC (15-240\%), FCC (maks. 35\%).

Tabel 3. Data analisis kandungan kadar abu (\%).

\begin{tabular}{ccccccc}
\hline \multicolumn{7}{c}{ Perlakuan (Hari) } \\
\hline Ulangan & $\mathbf{0}$ & $\mathbf{1 0}$ & $\mathbf{2 0}$ & $\mathbf{3 0}$ & $\mathbf{4 0}$ & $\mathbf{5 0}$ \\
\hline 1 & 18,35 & 20,95 & 22,08 & 14,76 & 20,66 & 18,08 \\
2 & 15,20 & 20,07 & 22,81 & 17,63 & 22,85 & 18,07 \\
\hline Total & 33,55 & 41,02 & 44,89 & 32,39 & 43,51 & 36,15 \\
\hline Rata- rata & 16,77 & 20,51 & 22,44 & 16,19 & 21,75 & 18,07 \\
\hline
\end{tabular}

Dari histogram, kadar abu tertinggi dihasilkan pada perlakuan 20 hari yaitu sebesar 22,44 persen dan yang terendah pada perlakuan 30 hari yaitu sebesar 16,19 persen. Kandungan abu menunjukan besarnya kandungan mineral pada karaginan yang tidak terbakar selama proses pengabuan. Rumput laut termasuk bahan pangan yang mengandung mineral yang cukup tinggi seperti $\mathrm{Na}, \mathrm{Ca}, \mathrm{K}, \mathrm{Cl}, \mathrm{Mg}, \mathrm{Fe}, \mathrm{S}$, dan trace element terutama iodium (Sukri, 2006). Hal ini diduga berpengaruh pada kandungan kadar abu yang dihasilkan karaginan.

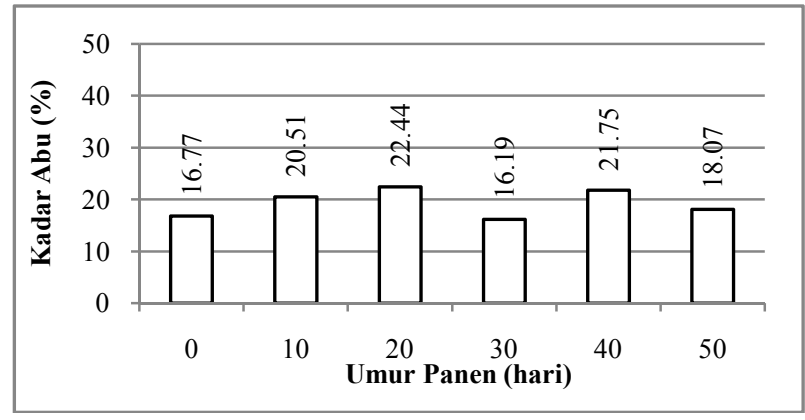

Gambar 3. Grafik kadar abu karaginan pada umur panen yang berbeda.

\section{Viskositas}

Pengujian viskositas dilakukan untuk mengetahui tingkat kekentalan karaginan sebagai konsentrasi pada konsentrasi dan suhu tertentu (Wenno, 2009). Nilai viskositas yang diperoleh dari penelitian ini rata-rata berkisar 
pada 60-85 cps, nilai viskositas tertinggi diperoleh dari perlakuan 0 hari (bibit) sedangkan nilai viskositas terendah diperoleh dari perlakuan 20 dan 50 hari.

Tabel 4. Data analisis nilai viskositas (\%).

\begin{tabular}{|c|c|c|c|c|c|c|}
\hline \multicolumn{7}{|c|}{ Perlakuan (Hari) } \\
\hline Ulangan & $\mathbf{0}$ & 10 & 20 & 30 & 40 & 50 \\
\hline 1 & 80 & 70 & 60 & 60 & 70 & 60 \\
\hline 2 & 90 & 70 & 60 & 70 & 70 & 60 \\
\hline Total & 170 & 140 & 120 & 130 & 140 & 120 \\
\hline Rata- rata & 85 & 70 & 60 & 65 & 70 & 60 \\
\hline
\end{tabular}

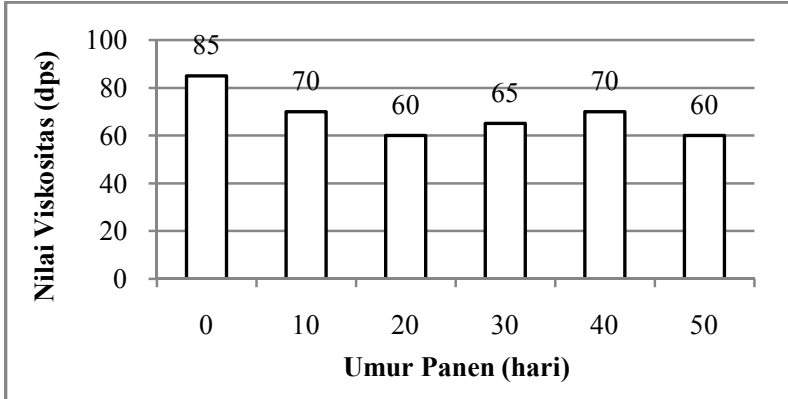

Gambar 4. Grafik nilai viskositas karaginan pada umur panen berbeda.

Viskositas pada karaginan disebabkan oleh adanya daya tolak menolak antar gugus sulfat yang bermuatan negatif disepanjang rantai polimernya, sehingga menyebabkan rantai polimer kaku dan kencang. Sifat hidrofilik menyebabkan molekul tersebut dikelilingi oleh air yang tidak bergerak, hal inilah yang menentukan nilai kekentalan karaginan (Guiseley et al., 1980 dalam sukri, 2006). Towle (1973) dalam Samsuar (2006), menyatakan bahwa viskositas karaginan dipengaruhi oleh beberapa faktor yaitu, konsentrasi karaginan, temperatur, tingkat dispersi, kandungan sulfat, dan berat molekut karaginan.

\section{Kekuatan Gel}

Salah satu sifat penting karaginan adalah mampu mengubah cairan menjadi padatan atau mengubah bentuk sol menjadi gel yang bersifat reversible. Kemampuan inilah yang menyebabkan tepung karaginan sangat luas penggunaannya, baik dalam bidang pangan maupun non pangan (Wenno, 2009). Kekuatan gel yang dihasilkan dalam penelitian ini berkisar dari 34,95-78,505 $\mathrm{g} / \mathrm{cm}^{2}$, Hasil yang diperoleh ini masih jauh di bawah standar yang ditetapkan yaitu $900-1200 \mathrm{~g} / \mathrm{cm}^{2}$.

Kekuatan gel tertinggi diperoleh dari perlakuan 50 hari $\left(78,505 \mathrm{~g} / \mathrm{cm}^{2}\right)$ sedangkan yang terendah diperoleh pada perlakuan 0 hari $\left(34,95 \mathrm{~g} / \mathrm{cm}^{2}\right)$. Secara umum pada gambar 5 terlihat kekuatan gel cenderung meningkat seiring bertambahnya umur panen, hal ini disebabkan karena pertambahan umur panen akan meningkatkan 3,6-anhidrogalaktosa menyebabkan meningkatnya potensi pembentukan heliks rangkapnya sehingga pembentukan gel lebih cepat dicapai (Moirano, 1977 dalam Samsuar 2006).

Tabel 5. Data analisis kandungan kadar abu (\%).

\begin{tabular}{c|c|c|c|c|c|c}
\hline \multicolumn{7}{c}{ Perlakuan (Hari) } \\
\hline Ulangan & 0 & 10 & 20 & 30 & 40 & 50 \\
\hline 1 & 18.35 & 20.95 & 22.08 & 14.76 & 20.66 & 18.08 \\
\hline 2 & 15.2 & 20.07 & 22.81 & 17.63 & 22.85 & 18.07 \\
\hline Total & 33.55 & 41.02 & 44.89 & 32.39 & 43.51 & 36.15 \\
\hline Rata- rata & 16.77 & 20.51 & 22.44 & 16.19 & 21.75 & 18.07 \\
\hline
\end{tabular}

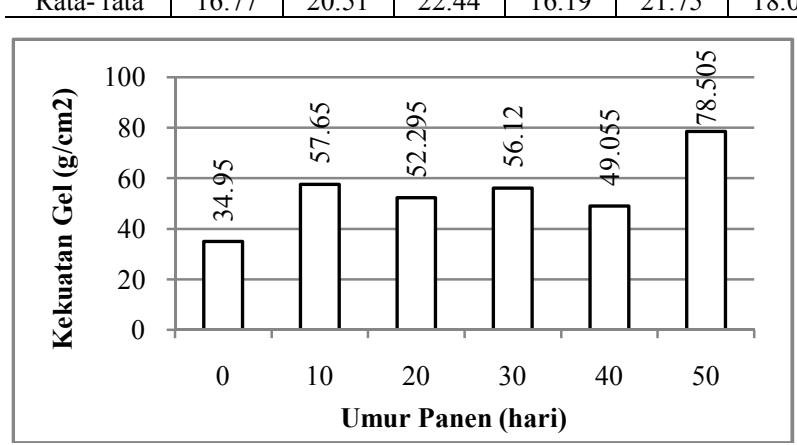

Gambar 5. Grafik kekuatan gel pada umur panen yang berbeda.

Hasil kekuatan gel yang diperoleh berbanding terbalik dengan nilai viskositas, dimana tingginya nilai viskositas maka kekuatan gel yang diperoleh sangat renah begitupula sebaliknya. Hal ini diduga karena penggunaan $\mathrm{NaOH}$ pada proses ekstraksi, dimana $\mathrm{Na}+$ menyebabkan rendemen karaginan yang kental dengan kekuatan gel yang rendah(Rasyid, 2003 dalam Alam, 2011).

Jenis penggunaan basa juga berpengaruh pada rendemen, kekuatan gel. Pada penelitian terdahulu, menunjukan bahwa ekstraksi karaginan menggunakan $\mathrm{KOH}$ berpengaruh pada kenaikan rendemen (Syamsuar, 2006). Menurut andriani (2006) dalam Hakim dkk., (2011) adanya penggunaan $\mathrm{KOH}$ selama proses ekstraksi, berperan sebagai stabilizer dengan meningkatkan titik leleh karaginan diatas suhu pemansnya $\left( \pm 80^{\circ} \mathrm{C}\right)$ sehingga tidak larut menjadi pasta.

Penggunaan $\mathrm{KOH}$ dalam proses ekstraksi juga mampu meningkatkan kekuatan gel kappa karaginan. Hal ini disebabkan karena kappa karaginan sensitif terhadap ion $\mathrm{K}^{+}$yang mampu meningkatkan kekuatan ionik dalam rantai polimer karaginan sehingga gaya antar molekul terlarut semakin besar yang menyebabkan keseimbangan antara ion-ion 
yang larut dengan ion-ion yang terikat di dalam struktur karaginan dapat membentuk gel (Hakim $d k k ., 2011$ ).

\section{KESIMPULAN DAN SARAN}

\section{Kesimpulan}

Hasil penelitian ini, menunjukan bahwa karakteristik sifat fisika kimia yang dipengaruhi oleh umur panen adalah kadar air dan viskositas. Hasil yang baik dari penelitian ini diperoleh dari perlakuan diatas umur 10 hari. Parameter kandungan rendemen tertinggi diperoleh pada hari ke 20 (28,402\%), kadar air terendah diperoleh pada hari ke $30(13,76 \%)$, kadar abu terendah diperoleh pada hari ke 30 $(16,19 \%)$, nilai viskositas terendah diperoleh pada hari ke 20 dan 50 (60 cps) dan kekuatan gel tertinggi diperoleh pada hari ke $50(78,505$ $\left.\mathrm{g} / \mathrm{cm}^{2}\right)$. Berdasarkan hasil parameter yang diukur dalam penelitian ini, maka rumput laut $K$. alvarezii yang ada di desa Arakan sudah bisa dipanen sejak umur 20 hari.

\section{Saran}

Pemanenan untuk pemanfaatan karaginan sebaiknya dilakukan pada umur 50 hari karena memiliki kekuatan gel yang paling baik. Perlu adanya penelitian areal lokasi pembudidayaan rumput laut $K$. alvarezii di perairan desa Arakan. Perlu adanya penelitian pembanding penggunaan basa pada proses ekstraksi untuk nilai viskositas dan kekuatan gel.

\section{DAFTAR PUSTAKA}

Alam A., 2011. Kualitas Karaginan Rumput Laut Jenis Euchema spinosum Di Perairan Desa Punaga
Kabupaten Tahalar. Konsentrasi Eksplorasi Sumber Daya Hayati Laut, Jurusan Ilmu Kelautan Dan Perikanan. Universitas Hasanudin. Makasar.

Anonimous, 2010. Perlu Kajian Pasar Rumput Laut Media Agribisnis Peternakan dan perikanan http://www.trobos.com/showarticle.php?rid=13\&aid= 2391.

Anonimous, 2011a. Produksi Rumput Laut indonesia Geser Filipina. Info Media. http://www. kkp.go.id/index.php/arsip/c/4060/Produksi RumputLaut-Indonesia-Geser-Filipina/.

Anonimous, 2011b. Investasi Rumput Laut Makin Unggul. Info Media. http://www.kkp.go.id/ index.php/arsip/c/6394/Investasi-Rumput-LautMakin-Unggul/

Emma S. $d k k$., 2010. Pelestarian Plasma Nutfah Rumput Laut Kappaphycus alvarezii (Doty) Melalui Induksi Kalus Dan Embriogenesis Secara Invitro. Badan Riset Perikanan Budidaya air Payau. Pusat Riset Perikanan Budidaya Kementrian Kelautan Dan Perikanan.

Hakim A. R., $d k k$., 2011. Pengaruh Perbandingan Air Pengekstrak, Suhu Prespitasi, Dan Konsentrasi Kalium Klorida (KCL) Terhadap Mutu Karaginan. Jurnal Pasca Panen dan Bioteknologi Kelautan dan Perikanan Vol. 6 No.1.

Harikedua J. W., 2003. Metode Analisa Kimia Hasil Perikanan. Fakultas Perikanan Dan Ilmu Kelautan. Universitas Sam Ratulangi. Manado.

Sukri N., 2006. Karakteristik Alkali Tread cottonii (ATC) Dan Karaginan Dari Rumput Laut Euchema cottonii Pada Umur Ppanen Yang Berbeda. Program Studi Teknologi Hasil Perikanan Fakultas Perikanan dan Ilmu Kelautan. Institut Pertanian Bogor.

Syamsuar, 2006. Karakteristik Karaginan Rumput Laut Euchema cottonii Pada Berbagai Umur Panen, Konsentrasi KOH Dan Lama Ekstraksi. Pasca Sarjana Institut Pertanian Bogor.

Wenno M. R., 2009. Karakteristik Fisiko-Kimia Karaginan Dari Euchema cottonii Pada Bagian Thalus, Berat Bibit dan Umur Panen. 